\title{
Development of Lectora Based PJOK Digital Learning Media on Floor Gunning Materials (Artistic)
}

\author{
Zulbahri $^{*}$ and Yuni Astuti ${ }^{2}$ \\ ${ }^{12}$ Dep. of Sport Education, Faculty of Sport Science, Padang State University, Padang, Indonesia \\ *Corresponding author.Email:zulbahri@fik.unp.ac.id (1) yuniastuti@fik.unp.ac.id (2)
}

\begin{abstract}
This research is based on the development of lectora-based digital learning media in the subject of Physical Education, Sports and Health with floor exercise (artistic) material. The research objective was to produce a digital-based learning media product for PJOK, making it easier for students and students in learning gymnastics. The sample of this research is FIK UNP students with gymnastics courses and gymnastics learning with a total of 12 people for small group subject trials and 15 people for field trials. The data obtained in this study are qualitative data obtained through validation from material experts, media experts and quantitative data obtained through assessment questionnaire analysis with descriptive statistics. This research was conducted using "Research and Development" (Research and Development). The model used as a reference is the Borg \& Gall development research model with 10 developments, in this study the researcher adopted 7 steps, with the following stages: 1) Preliminary study (research and data collection). 2) Prepare a plan and analyze the media to be made. 3) Initial product development by producing learning media with validation by media experts and material experts. 4) Conduct small group trials. 5) Product Revisions. 6) Conduct field trials. 7) Revise the final product. For this early stage research, it has only arrived at the fourth stage (4), namely conducting small group trials. Hail Research in the form of The model used as a reference is the Borg \& Gall development research model with 10 developments, in this study the researcher adopted 7 steps, with the following stages: 1) Preliminary study (research and data collection). 2) Prepare a plan and analyze the media to be made. 3) Initial product development by producing learning media with validation by media experts and material experts. 4) Conduct small group trials. 5) Product Revisions. 6) Conduct field trials. 7) Revise the final product. For this early stage research, it has only arrived at the fourth stage (4), namely conducting small group trials. Hail Research in the form of The model used as a reference is the Borg \& Gall development research model with 10 developments, in this study the researcher adopted 7 steps, with the following stages: 1) Preliminary study (research and data collection). 2) Prepare a plan and analyze the media to be made. 3) Initial product development by producing learning media with validation by media experts and material experts. 4) Conduct small group trials. 5) Product Revisions. 6) Conduct field trials. 7) Revise the final product. For this early stage research, it has only arrived at the fourth stage (4), namely conducting small group trials. Hail Research in the form of 1) Preliminary Study (research and data collection). 2) Prepare a plan and analyze the media to be made. 3) Initial product development by producing learning media with validation by media experts and material experts. 4) Conduct small group trials. 5) Product Revisions. 6) Conduct field trials. 7) Revise the final product. For this early stage research, it has only arrived at the fourth stage (4), namely conducting small group trials. Hail Research in the form of 1) Preliminary Study (research and data collection). 2) Prepare a plan and analyze the media to be made. 3) Initial product development by producing learning media with validation by media experts and material experts. 4) Conduct small group trials. 5) Product Revisions. 6) Conduct field trials. 7) Revise the final product. For this early stage research, it has only arrived at the fourth stage (4), namely conducting small group trials. Hail Research in the form of just arrived at the fourth stage (4), namely conducting small group trials. Hail Research in the form of just arrived at the fourth stage (4), namely conducting small group trials. Hail Research in the form ofdigital learning media products in gymnastics learning (artistic) for practice materials obtained a score of 3.67 with good criteria and for media a score of 3.3 which was categorized quite good.
\end{abstract}

\section{Keywords: Digital Learning Media, Lectora, Floor Gymnastics}

\section{INTRODUCTION}

Basically, floor or artistic gymnastics is one of the most popular sports achievements in society and the world. Apart from sports of achievement, artistic gymnastics is also a branch of educational sports developed in school and lecture curricula.Gymnastics is a word that translates directly from English, namely gymnastik. Gymnastics are used to show physical activities that require breadth and freedom of movement, so it needs to be done using tight clothing 
(press body) [1, 14]. From the characteristics and structure of the movement, gymnastics can be said to be a physical or bodily activity that is suitable to be used as a tool in physical education, because it is considered capable of contributing to the quality of the development of motor aspects and physical qualities. The characteristics of motion are very important in increasing understanding of the principles of mechanics of motion and the laws of nature that work on a body that is in constant motion. Skills in artistic gymnastics are always built on basic skills consisting of; (a) locomotor skills, namely moving places such as walking and jumping. (b) Non locomotor skills, namely movements that do not move places such as bending. (c) Manipulative skills, namely manipulating certain objects with limbs: hands, head and feet.[2, 3, 14]

On implementation or the learning process in schools or lectures, floor or artistic exercises including motor activities that need to be extra careful to practice them, because the risk of injury is also high if an error occurs in a series of movements. Therefore, there are also many students and students who are hesitant, afraid or anxious to practice it in learning. In addition to these problems, PJOK teachers in schools, especially those in the regions, also find it difficult to carry out floor or artistic gymnastics learning due to the lack of knowledge and media that can be used as examples, references and learning benchmarks. In the implementation of this research, the learning media for floor exercise will be developed in the form ofdigital. Learning media that are made contain the flow and steps in a series of movements as well as a form of assistance developed to make it easier for teachers to teach gymnastics movements to students or lecturers to students. The mechanism for making media is to digitize learning carried out by teachers and lecturers in the class. The concept of implementing the work is to provide examples by demonstrating a series of movements and digital aids to make it easier for teachers and lecturers to direct and evaluate students / students in learning, so as to create effective and efficient learning. And students can learn to practice outside class hours or in the application of extracurricular activities.

Special purpose in the implementation of this research is to design a floor gymnastics or artistic learning media that utilizes technology, so that it is expected to be able to answer the problems that have been faced. This research is in accordance with one of the research master designs of Padang State University related to the development of technology, media, sports modules and instruments.

\section{LITERATURE REVIEW}

Learning that is "Learning is relatively permanent change in behavior that result from past experience or purposeful instruction". From this explanation, we can conclude that learning is a process of changing attitudes and behaviors permanently resulting from experiences and the learning process [4]. Whereas what is meant by learning is the arrangement and creation of certain conditions in such a way that it supports the student learning process and does not hinder it. [2,4,5]

In its implementation at school and in lectures, learning is developed with several branches of knowledge in accordance with the goals and results to be achieved through this learning, including Sports and Health Physical Education. Sports and Health Physical Education subjects are part of general education in schools aims to develop aspects of physical fitness, movement skills, critical thinking skills, social skills, reasoning, emotional stability, moral action, aspects of a healthy lifestyle and introduction. Sports and health are subjects taught at every level of education.2,6].

In the 2013 curriculum, the scope of physical education is no different from the previous curriculum, there are seven aspects developed, among them are gymnastics activities: simple dexterity, dexterity without tools, dexterity with tools, and floor exercises, and other activities. Gymnastics is a physical activity with the richest movement structure "[1,2,17]. From the characteristics and structure of the movement, gymnastics can be said to be a suitable physical activity as a physical education tool, because it is considered capable of contributing to the quality of motor development and physical quality"[2,7]. The characteristics of motion are very important in increasing understanding of the mechanics of motion principles and the laws of nature that act on a moving body. Gymnastics skills are always built on basic skills consisting of: (a) locomotor skills, namely moving places such as roads and jumps. (b) Non-locomotor skills, which are movements that do not move places, relying on the joints of the body to form different positions that remain in one point such as bending. (c) Manipulative skills, namely manipulating certain objects with limbs: hands, head and feet [1,2]. All these steps are neatly arranged in one basic technique. The basic technique is a mastery of a technique in which the process of doing it is fun-damaging, which consists of a simple and easy-to-do movement of the motion process $[2,13]$.

To make it easier to practice gymnastics movements, it is necessary to use a direct assistance approach (direct assistance approach) which is a form of training with the involvement of friends to help each other in movement activities and the indirect assistance 
approach with the help of tools. In other words, when assistance is given, teachers and lecturers can try to correct the mistakes or deficiencies of students in the process of movement so that it will certainly accelerate the mastery of motor skills when performing movements compared to exercises carried out individually $[2,3]$. On the other hand, the direct and indirect support approaches will also reduce the risk of injury when practicing gymnastics skills. This approach to help can be used for various forms of exercise such as standing with two hands (handstand), rolling head stand, cart, etc. All the steps and forms of training aids in floor gymnastics learning will be published in a learning medium [2]. In order to carry out learning well, of course with the help of this media it will provide more motivation to students, as for the motivation function there are 3 (three) things, namely: 1)encourage men to do. Motivation in this case is the motor of each activity to be carried out. 2) Action directed, namely towards the goal to be achieved, that is the motivation to provide direction, and activities that must be carried out in accordance with the formulation of goals. 3) Choosing an action, an act that determines what should be done to match to achieve the goal, by setting aside actions that are not useful for that purpose [15].

The media or what is called the medium serves as an introduction to convey information from sender to receiver. While the learning media, namely all materials and physical tools used to implement teaching and facilitate student achievement towards teaching objectives.2,8]. Learning media as a tool in the learning process can be used inside and outside the classroom. The media is used for communication and interaction between teachers and students in the learning process [2,5]. In this study, learning media is made based on lectora, which is a message conveying tool that combines two or more media elements, including text, images, graphics, photos, sound, film and animation in an integrated manner packaged in a digital versatile disc. $[2,5,9]$.Lectorais a Software Authoring Tool for content development in E-Learning developed by the Trivantis Corporation. Its founder is Timothy D. Loudermilk in Cincinnati, Ohio, USA in 1999. In 2000, Lectora became the first AICC-certified authoring system on the market [16]. This achievement greatly gave Lectora the credibility needed to gain acceptance in the e-learning industry so that it can easily be developed in learning. Furthermore, in 2011 Lectora was awarded in the field of innovative E-Learning products, Authoring tools, the best presentation tools and the best E-Learning technology, thus making Lectora the choice to be developed in the world of education [16]. The advantages of lectora are:
1) It is easy to use by anyone who is not proficient or even proficient with complex programming languages.

2) Multifunctional, which can be used to create websites, interactive E-Learning content and also product presentations or company profiles.

3) Has many features ranging from sound, images, videos to fairly complete templates.

4) Provides 8 types of questions that are easy to apply, accompanied by scores and evaluations.

5) Nisa developed content published to various outputs, for example: HTML, its function is to be displayed as a website on the internet.

6) Single File Executable (.exe), can be opened on a PC / Laptop that does not have Lectora software.

7) Flypaper is used to combine images, video, flash, transition animation, and game memory. This software can generate files in the form of swf so that it can be easily integrated with Lectora Inspire easily.

8) Snagit is used to capture the monitor screen. This is a screen print technology. Usually, if we use a screen print, the image must first be inserted into Paint so that it takes a long time. With this snagit, you can immediately capture and edit images. Snagit can be used to combine several images into one and can be published in various image files.

9) Camtasia is used to record the steps we take on the monitor screen. This software can also be used to edit videos and can be published into standard video formats [16]

Development of lectora-based learning media which contains steps and techniques direct and indirect assistance approachfirst this is done in learning gymnastics, because so far there has never been a media development with this approach, so it has a high novelty value. This is the first step that is believed to be able to make learning gymnastics a sport that students like. Apart from the use of technology, the achievement of learning achievement in gymnastics is determined by many other factors.

\section{METHOD}

This research was conducted with Research and Development namely the research methods used to produce certain products, and testing the effectiveness of these products. The research sample was 15 students of PO FIK UNP. Research and Development aims to find new knowledge through "basic research" or to answer specific questions about practical problems through "applied research" which is used to improve educational practices [12]. In this study, Research and Development was used to produce digital versatile disk learning media. 
Based on the 10 development steps developed by Borg and Gall, the researcher adopts the following stages:

1) Preliminary Study (research and data collection). Conducting observations, interviews and field observations.

2) Compiling a Plan. Researchers plan and analyze the learning media that will be made.

3) Early product development. Researchers produce learning media. After the production is complete, then validation is carried out by media experts and material experts.

4) Conduct small group trials. The revised media was based on one-on-one trials and was then tried out in small groups with a total of 12 students.

5) Product Revisions. Fix media errors and flaws

6) Conduct field trials. The number of students in the operational group trial was 15 people.

7) Revise the final product. The main field trial data is used as reference material in product revisions and is the final result in media development. [11]

The work plan in this research is designing digital versitale disk, then validated by media experts and material experts, then conducted trials in small groups and large groups until the final product revision stage as finalization in media development.

\section{RESEARCH RESULTS AND DISCUSSION}

4.1 Validation and Revision Phase II by Material and Media Experts

Validators who are material experts and media experts in this development research are a Gymnastics Lecturer in the Sports Education Department and Doctoral students of Educational Technology UNP as well as a Vocational School Media and Technology teacher.

Validation is done by providing a form of learning media. In this validation, researchers and material experts discuss the quality of the material in learning media. The evaluation provided by the material expert in the form of a per item description of the basic movements included with photos of the movement steps to make them more visible, to clarify the phases and smoothness of the movements carried out. Phase I evaluation was carried out on August 23, 2020, and the following data were obtained:
Table 1.The Score of Quality Aspects of Learning material by Phase I Material Experts

\begin{tabular}{|c|c|c|c|c|c|c|c|}
\hline \multirow[b]{2}{*}{ No. } & \multirow[b]{2}{*}{ Rated aspect } & \multicolumn{5}{|c|}{ Skappraisal } & \multirow[b]{2}{*}{ Kiteria } \\
\hline & & 1 & 2 & 3 & 4 & 5 & \\
\hline 1. & $\begin{array}{c}\text { Overall Movement } \\
\text { Accuracy }\end{array}$ & & & $\sqrt{ }$ & & & $\begin{array}{l}\text { Pretty } \\
\text { good }\end{array}$ \\
\hline 2. & $\begin{array}{c}\text { Movement Phase } \\
\text { Accuracy }\end{array}$ & & & $\sqrt{ }$ & & & $\begin{array}{l}\text { Pretty } \\
\text { good }\end{array}$ \\
\hline 3. & $\begin{array}{c}\text { The subtlety and } \\
\text { beauty of movement }\end{array}$ & & & $\sqrt{ }$ & & & $\begin{array}{c}\text { Enough } \\
\text { Baik }\end{array}$ \\
\hline & amount & $\mathbf{0}$ & $\mathbf{0}$ & 6 & 4 & $\mathbf{0}$ & \\
\hline & Total score & & & 9 & & & Cgood \\
\hline & Average score & & & 3 & & & \\
\hline
\end{tabular}

Then for media validation it is done by providing a form of learning media. In this validation, researchers and media experts discuss the quality of videos and images in learning media. The evaluation given by media experts in the form of room lighting needs attention. Phase II evaluation was carried out on August 25, 2020, and the following data were obtained:

Table 2. Score of Quality Aspects of Learning material by Stage II Media Experts

\begin{tabular}{|c|c|c|c|c|c|c|c|}
\hline \multirow[b]{2}{*}{ No. } & \multirow[b]{2}{*}{ Rated aspect } & \multicolumn{5}{|c|}{ Skappraisal } & \multirow[b]{2}{*}{ Kiteria } \\
\hline & & 1 & 2 & 3 & 4 & 5 & \\
\hline 1. & $\begin{array}{l}\text { Video and Image } \\
\text { Media Lighting }\end{array}$ & & & $\sqrt{ }$ & & & $\begin{array}{l}\text { Pretty } \\
\text { good }\end{array}$ \\
\hline 2. & $\begin{array}{c}\text { Clarity of Video } \\
\text { and Media Images }\end{array}$ & & $\sqrt{ }$ & & & & Not good \\
\hline \multirow[t]{3}{*}{3.} & $\begin{array}{c}\text { Side recording } \\
\text { Video and Image } \\
\text { gestures }\end{array}$ & & $\sqrt{ }$ & & & & Less Baik \\
\hline & amount & $\mathbf{0}$ & 4 & 3 & $\mathbf{0}$ & $\mathbf{0}$ & \\
\hline & Total score & \multicolumn{5}{|c|}{7} & \multirow[t]{2}{*}{ Not good } \\
\hline & Average score & \multicolumn{5}{|c|}{2.33} & \\
\hline
\end{tabular}

\section{CONCLUSIONS}

Be Based on the results of research on the development of floor exercise learning media products, it can be concluded that the steps taken in the development of learning media are carried out in several stages, namely; the preliminary stage which consists of analyzing the needs and determining the 
material, the initial product-making stage, the evaluation stage which consists of validation of material experts and media experts, small group trials and field trials. For this early stage research, it has only arrived at the fourth stage (4), namely the initial stage of validation by media experts and material experts. SeHaving carried out the development stage, the resulting learning media product until the initial or first stage revision for practical material with a score of 3 with a fairly good criterion and for media with a score of 2.33 with a poor category.

\section{ACKNOWLEDGMENTS}

The completion of this research is something that is very grateful for. For this reason, researchers and the team would like to thank those who have contributed to the completion of this research. Among them are LP2M UNP which has provided support in terms of research funding, then FIK UNP which has provided opportunities as a provider of facilities and infrastructure for research. Hopefully this research is useful for all of us.

\section{REFERENCES}

[1] Hedbávný Petr. 2013. "Balancing In Handstand On The Floor". Czech: Faculty of Sports Studies, Masaryk University, Brno. Science of Gymnastics Journal

[2] Zulbahri, Z. (2020). PENGEMBANGAN MEDIA BELAJAR PJOK PADA MATERI SENAM LANTAI (ARTISTIK). Jurnal Ilmu Keolahragaan Undiksha, 8(2).

[3] Tim Pengajar UPI. 2012. Modul 2 "Pendekatan Mengajar Senam dan Hakikat Bantuan". File UPI. Bandung

[4] Eveline Siregar \& Hartini Nara. (2011). Teori Belajar dan Pembelajaran (cetakan kedua). Bogor: Ghalia Indonesia.

[5] Didi Supriadie \& Deni Darmawan. (2012). Komunikasi Pembelajaran. 2012. Bandung: PT Remaja Rosadakarya.

[6] Kemendikbud. (2014). Buku Guru Pendidikan Jasmani, Olahraga, dan Kesehatan. Jakarta: Kementrian Pendidikan danKebudayaan.

[7] Margono, Agus. Dkk. 2012. Modul PLPG "Pendalaman Materi PENJAS". Surakarta.

[8] Arief S. Sadiman, dkk. (2011). Media Pendidikan: Pengertian, Pengembangandan Pemanfaatannya. Jakarta : PT Raja Grafindo Persada.

[9] Cecep Kustandi \& Bambang Sutjipto. (2013). Media Pembelajaran : Manual dan Digital. Bogor : Ghalia Indonesia.
[10] Nurhasan. 2014. Implementasi ilmu pengetahuan dan teknologi pada prestasi olahraga. Prosiding seminar nasional olahraga kesehatan dan prestasi (surabaya: fk- unair:2014)

[11] Gall. 2013. Borg, walter r. And gall, meredith d. Education research: an introduction, 8th edition. New york: longman inc.,

[12] Sugiyono. (2011). Metode Penelitian Kuantitatif, kualitatif dan R\&D. Bandung: Alfabeta.

[13] Zulbahri, Z., \& Melinda, C. (2019, May). Metode practice style dan guided discovery style serta keterampilan teknik dasar atlet bulutangkis. In Prosiding Seminar Nasional Fakultas Ilmu Kesehatan dan Sains (Vol. 1, No. 1).

[14] Zulbahri, Z. (2016). Pengaruh Pendekatan Bantuan Langsung Terhadap Keterampilan Handstand. Edu Research, 5(2), 105-112.

[15] Susanto, N., \& Sari, D. N. (2020, August). Role of Motivation, Creativity, Affective and Implications in the Teaching and Learning Process of Physical Education. In 1st International Conference of Physical Education (ICPE 2019) (pp. 286-288). Atlantis Press.

[16] https://duniapendidikan.co.id/

[17] Pitnawati, P., Damrah, D., \& Zulbahri, Z. (2019). Analysis of Motivation to Learn and Motion Gymnastics Sequentially Dexterity Primary School Students. International Journal of Research and Innovation in Social Science (IJRISS), 3(8), 233-236. 